\title{
Biochemical and morpho-anatomical analyses of strawberry vitroplants hyperhydric tissues affected by $\mathrm{BA}$ and gelling agents
}

\author{
Leticia Mascarenhas Pereira Barbosa ${ }^{1}$, Vespasiano Borges de Paiva Neto ${ }^{2}$, Leonardo Lucas Carnevalli Dias ${ }^{3}$, \\ Reginaldo Alves Festucci-Buselli ${ }^{4}$, Rodrigo Sobreira Alexandre ${ }^{5}$, Lourdes Iarema ${ }^{6}$, \\ Fernando Luis Finger ${ }^{7}$, Wagner Campos Otoni ${ }^{8}$
}

\begin{abstract}
In vitro propagation has become an effective practice for large-scale production of strawberry plants. The objective of this study was to evaluate the hyperhydricity and the multiplication capacity of two strawberry varieties (Fragaria $x$ ananassa Duch. 'Dover' and 'Burkley') propagated in vitro. Plants maintained in MS medium supplemented with 1.0 $\mathrm{mg} \mathrm{L}^{-1} \mathrm{BA}$ were individualized and transferred to the same medium solidified with Agar $\left(6.5 \mathrm{~g} \mathrm{~L}^{-1}\right)$ or Phytagel ${ }^{\circledR}\left(2.5 \mathrm{~g} \mathrm{~L}^{-1}\right)$ and BA at different concentrations $\left(0 ; 0.5 ; 1.0 ; 2.0\right.$ and $\left.3.0 \mathrm{mg} \mathrm{L}^{-1}\right)$. Biochemical and anatomical analyses were carried out, as well as the analysis of the morphological hyperhydricity characteristics. The analysis of data showed: a) the increase in cytokinin concentration increased hyperhydricity frequency in both varieties; b) at concentrations up to $2.0 \mathrm{mg} \mathrm{L}^{-1} \mathrm{BA}$, the replacement of Agar by Phytagel ${ }^{\circledR}$ induced a higher formation of hyperhydric shoots; and c) the addition of BA induced oxidative stress, which is characterized by increased antioxidant activity and lipid peroxidation, as well as alterations at the cellular level, such as malformation of stomata and epidermal cells. In conclusion, the culture medium containing $0.5 \mathrm{mg} \mathrm{L}^{-1} \mathrm{BA}$ solidified with Agar provided lower hyperhydricity percentages in association with higher rates of shoot proliferation in strawberry.
\end{abstract}

Key words: oxidative stress; cytokinin; lipid peroxidation; micropropagation.

\section{RESUMO}

\section{Análises bioquímicas e morfo-anatômicas em vitroplantas de morangueiro hiper-hídricas afetadas pelo BA e agentes geleificantes}

A propagação in vitro tem se destacado como uma técnica efetiva na produção em larga escala de plantas sadias de morangueiro. Neste trabalho estudamos a hiperhidricidade associado a capacidade de multiplicação in vitro na propagação de duas variedades de morangueiro (Fragaria x ananassa Duch. "Dover" e "Burkley"). Plantas mantidas em meio de cultura MS, suplementadas com $1.0 \mathrm{mg} \mathrm{L}^{-1}$ de BA fora individualizadas e transferidas para o mesmo meio com Ágar $\left(6.5 \mathrm{~g} \mathrm{~L}^{-1}\right)$ ou Phytagel ${ }^{\circledR}\left(2,5 \mathrm{~g} \mathrm{~L}^{-1}\right)$ e BA em diferentes concentrações $\left(0 ; 0,5 ; 1,0 ; 2,0\right.$ e 3,0 mg L $\left.^{-1}\right)$. Foram realizadas análises bioquímica e anatômicas, além da caracterização morfológica do material hiper-hídrico. A análise

\footnotetext{
Received: 05/03/2012; Accepted: 04/03/2013

${ }^{1}$ Biologist, Master of Science. Departamento de Biologia Vegetal, Universidade Federal de Viçosa, Campus Viçosa, Avenida Peter Henry Rolfs, s/n, 36570-000, Viçosa, Minas Gerais, Brasil. leticiampb@yahoo.com.br

2Agronomist Engineer. Universidade Federal de Mato Grosso do Sul, Campus Chapadão do Sul, 79560-000, Chapadão do Sul, Mato Grosso do Sul, Brasil. vespasiano@nin.ufms.br Agronomist Engineer, Doctor of Science. Departamento de Biologia Vegetal, Universidade Federal, Campus Viçosa, Avenida Peter Henry Rolfs, s/n, 36570-000 Viçosa, Minas Gerais, Brasil. carnevalli.dias@gmail.com (autor para correspondência).

${ }^{4}$ Agronomist Engineer. Centro de Tecnologia Agropecuária, Universidade Federal Rural da Amazônia, Avenida Tancredo Neves, 2501, 66077-530, Belém, Pará, Brasil. rfestuccibuselli@hotmail.com

${ }^{5}$ Agronomist Engineer. Departamento de Ciências Agrárias e Biológicas, Universidade Federal do Espírito Santo, Rodovia BR 101 Norte, Km 60, Bairro Litorâneo, 29932-540, São Mateus, Espírito Santo, Brasil. rodrigosobreiraalexandre@gmail.com

${ }^{6}$ Biologist, Ph.D. Departamento de Biologia Vegetal, Universidade Federal de Viçosa, Campus Viçosa, Avenida Peter Henry Rolfs, s/n, 36570-000, Viçosa, Minas Gerais, Brasil. lourdesiarema@yahoo.com.br

${ }^{7}$ Agronomist Engineer, Doctor of Science. Departamento de Fitotecnia, Universidade Federal de Viçosa, Campus Viçosa, Avenida Peter Henry Rolfs, s/n, 36570-000 Viçosa, Minas Gerais, Brasil. ffinger@ufv.br

${ }^{8}$ Agronomist Engineer, Doctor of Science. Departamento de Biologia Vegetal, Universidade Federal de Viçosa, Campus Viçosa, Avenida Peter Henry Rolfs, s/n, 36570-000 Viçosa, Minas Gerais, Brasil. wcotoni@gmail.com
} 
dos dados mostrou: a) o incremento na concentração de citocinina aumentou a freqüência de hiper-hidricidade para ambas as variedades; b) concentrações maiores que 2,0 $\mathrm{mg} \mathrm{L}^{-1}$ de BA, com a substituição do Ágar pelo Phytagel ${ }^{\circledR}$ induziu a maior formação de ramos hiper-hídricos; e c) a adição de BA induziu o estresse oxidativo, caracterizado pelo incremento da atividade antioxidante e peroxidação de lipídeos, bem como alterações a nível celular, como má formação dos estômatos e células epidérmicas. Concluindo, o meio de cultura contendo $0,5 \mathrm{mg} \mathrm{L}^{-1}$ de BA solidificado com Ágar promoveu menor porcentagem de hiper-hidricidade associado com maiores taxas de proliferação de gemas em morangueiro.

Palavras-chave: citocininas; estresse oxidativo; peroxidação de lipídeos; micropropagação.

\section{INTRODUCTION}

Strawberry (Fragaria $\mathrm{x}$ ananassa Duch.) is an herbaceous, perennial and stoloniferous plant that is vegetatively propagated through runners arising from the parent plant.

In vitro propagation of strawberries is an effective practice for large-scale plant production in a controlled and disease-free environment (Calvete et al. 2009). During in vitro culture, plants are grown under special conditions, such as reduction of gas exchange, high air humidity, low light intensity and the use of sugar as an energy source. These conditions may cause increased reserves or biomass accumulation, photosynthesis inhibition, and abnormal stomata development, which can lead to the development of hyperhydricity. Hyperhydricity hinders micropropagation and acclimatization, causing significant plant losses when vitroplants are transferred to ex vitro conditions (Jausoro et al. 2010).

Hyperhydricity is a well-studied phenomenon, but it is not predictable. It occurs due to external factors, independent of explant origin and, under specific conditions, evolves to loss of regenerative capacity of the tissue (Casanova et al. 2008). Increased agar concentration or other gelling agents reduce the availability of water, which reduces hyperhydricity (Ivanova \& van Staden 2011). However, it is often accompanied by a decrease in propagation frequency (Casanova et al. 2008; Gupta \& Prasad 2010).

The capacity of the antioxidant defense system often increases under stressful conditions (Sreedhar et al. 2009). The artificial conditions of in vitro culture may predispose tissues to the damaging effects of reactive oxygen species (ROS) (Balen et al. 2011). Higher levels of antioxidant enzymes have been correlated with oxidative stress and hence are considered molecular markers for such conditions (Wu et al. 2009).

This study was carried out to characterize hyperhydricity induced by different concentrations of BA and different gelling agents in the propagation of strawberry (Fragaria $\mathrm{x}$ ananassa) varieties 'Dover' and 'Burkley', in association with the capacity of in vitro shoot proliferation.

\section{MATERIAL AND METHODS}

\section{Plants and tissue culture}

The strawberry (Fragaria x ananassa) plants, varieties 'Dover' and 'Burkley', used in the experiments was kindly provided by the Plant Tissue Culture Laboratory of the Empresa Brasileira de Pesquisa Agropecuária - EMBRAPA Clima Temperado, Pelotas, RS, Brazil.

In vitro cultures were maintained under a $16 \mathrm{~h}$ photoperiod and $36 \mu \mathrm{mol} \mathrm{m}^{-2} \mathrm{~s}^{-1}$ light radiation provided by two fluorescent tubes ( $20 \mathrm{~W}$, Osram, Brazil). The culture room temperature was kept at $26 \pm 2{ }^{\circ} \mathrm{C}$. Once a month, the cultures were transferred to new medium consisting of MS basal salts (Murashige \& Skoog 1962) and vitamins, $30 \mathrm{~g} \mathrm{~L}^{-1}$ sucrose, $100 \mathrm{mg} \mathrm{L}^{-1}$ of myo-inositol, $6.5 \mathrm{~g} \mathrm{~L}^{-1}$ agar (Merck ${ }^{\circledR}$, Germany) and $1.0 \mathrm{mg} \mathrm{L}^{-1}$ of BA. The $\mathrm{pH}$ was adjusted to 5.8 before autoclaving at $120^{\circ} \mathrm{C}$ and $1.1 \mathrm{~Pa}$ for $20 \mathrm{~min}$.

\section{Experimental design}

To determine optimal culture conditions to obtain normal and hyperhydric plants, the plant material was isolated under aseptic conditions and transferred to 240 $\mathrm{mL}$ glass flasks containing $30 \mathrm{~mL}$ of MS medium with the same concentrations of sucrose and myo-inositol. The medium was solidified with either $6.5 \mathrm{~g} \mathrm{~L}^{-1}$ of granulated agar (Merck ${ }^{\circledR}$, Germany) or $2.5 \mathrm{~g} \mathrm{~L}^{-1}$ of Phytagel $^{\circledR}$ (Sigma Chem. Co., USA) and supplemented with different concentrations of 6-benzyladenine (BA).

The treatments consisted of culture media added with $0.0,0.5,1.0,2.0$ and $3.0 \mathrm{mg} \mathrm{L}^{-1} \mathrm{BA}$, and solidified with agar, or with Phytagel ${ }^{\circledR}$, resulting in ten treatments. Flasks were sealed with polyvinyl chloride film (PVC) (Goodyear, Brazil) and maintained in the culture room as described above.

The experimental unit consisted of one flask with 5 shoots each. The experiment was conducted in a 
completely randomized design with ten treatments and 5 replicates per treatment for each variety. Statistical analyses were performed and data were subjected to analysis of variance (ANOVA) and, when appropriate, means were compared using the Tukey's test at 5\% probability.

\section{Morphological analyses of hyperhydric plants}

Hyperhydricity evaluations began one week after culture initiation and were repeated every 3 days. At the end of the experiment ( 35 days after culture initiation), tissues were sampled for biochemical, anatomical, pigment (chlorophyll) and ethylene analysis. The following characteristics were evaluated: number of buds per shoot and percentage of hyperhydric buds.

\section{Anatomical and ultrastructural analyses}

Anatomical and ultrastructural analyses were performed using fully expanded leaves from normal and hyperhydric plants fixed according to Karnovsky (1965). Samples prepared for photonic microscopy were submitted to a vacuum treatment for $24 \mathrm{~h}$ and rinsed in $0.05 \mathrm{M}$ potassium phosphate buffer for $30 \mathrm{~min}$. Tissues were then dehydrated in an ethylic series and embedded in metacrilate (Historesin ${ }^{\circledR}$, Leica). The metacrilate blocks were sectioned using an automatic rotary microtome (Leica RM 2155-UK). The 5- $\mu$ m thick sections were stained with Toluidine blue for $11 \mathrm{~min}$ and mounted in Permount ${ }^{\circledR}$ (Fisher Scientific, USA). Anatomical observations were performed using a photomicroscope (Olympus AX70TRF, Tokyo, Japan) equipped with a U-photo system (Olympus, Japan).

Samples selected for scanning electron microscopy were dehydrated in an ethylic series, evaluated and micrographed using a scanning electron microscope (LEO 1430VP, Japan).

\section{Biochemical analysis}

The enzymatic extract used to determine peroxidase, catalase and superoxide dismutase activity was obtained by homogenizing $0.5 \mathrm{~g}$ of leaf tissue (frozen in liquid nitrogen at $-80{ }^{\circ} \mathrm{C}$ ) with $4 \mathrm{~mL}$ of extraction solution $(0.1$ $\mathrm{mM}$ EDTA in $0.1 \mathrm{M}$ potassium phosphate buffer, $\mathrm{pH}$ 6.8). All procedures were performed at $4{ }^{\circ} \mathrm{C}$.

Biochemical analyses were conducted according to different authors: Peroxidase activity (POD EC1.11.1.7) (Chance \& Maehley 1955); Catalase (CAT EC1.11.1.6) (Havir \& McHale 1987); and Superoxide Dismutase (SOD EC1.15.1.1) (Giannopolitis \& Ries 1977).

\section{Lipid peroxidation}

Lipid peroxidation was evaluated through the formation of malonaldehyde (MDA), a final product of lipid peroxidation, using the thiobarbituric acid test (TBA), according to Buege \& Aust (1978). The amount of the complex MDA-TBA was determined using the molar extinction coefficient of $1.56 \times 10^{-5} \mathrm{~mol}^{-1} \mathrm{~cm}^{-1}$ (Dhindsa et al. 1981).

\section{Chlorophyll analyses}

The chlorophyll content analysis was performed using hyperhydric and normal strawberry plants. Samples consisting of $100 \mathrm{mg}$ of fresh leaves were ground in a mortar with $80 \%$ acetone (w/w) and washed sand, and filtered with filter paper. After the first filtration the paper was washed in $80 \%$ acetone (w/w) to remove debris, and the filtered solution was poured into a volumetric flask. The flask was filled with $25 \mathrm{~mL}$ of solution and absorbance at 645 and 663 ç m was determined (Hendry \& Price 1993).

\section{RESULTS AND DISCUSSION}

\section{$B A$ induced both shoot proliferation and hyperhydric morphology}

Hyperhydricity is an undesirable physiological state and represents a potential barrier to the exploitation of in vitro propagation of several in vitro cultured plants. It causes a decrease in survival rate when plants are transferred to ex vitro conditions, resulting in considerable commercial losses (Rojas-Martinez et al. 2010).

In our study, for both evaluated varieties ('Dover' and 'Burkley'), the BA-free treatments resulted in plants without hyperhydricity. However, the rate of shoot proliferation was very low in BA-free media when compared to BA-supplemented media. According to Jain et al. (2001), growth regulator-free medium produces a high frequency of normal plants, while BA-supplemented medium leads to the development of hyperhydricity.

The first hyperhydricity symptoms were visualized at 9 and 12 days after subculture of the 'Burkley' and 'Dover' varieties, respectively. The hyperhydricity symptoms were characterized by the appearance of translucent and fragile leaves, with shorter shoots (Figure 1). The first new shoots showed abnormal development resulting in a rosette-like structure at the explant base that was largely immersed in the medium (Figure 1B), with explants characterized by thickened and slightly elongated internodes (Figure 1C). In both varieties, the rates of formation of new axillary shoots were significantly increased in BA-supplemented medium and, in both varieties, the formation of new shoots was higher in treatments using Phytage ${ }^{\circledR}$ as the gelling agent, with or without BA-supplement (Figure 2). The same efficiency for shoot proliferation was observed by Kumar et al. (2010).

In treatments using agar as the gelling agent, the formation of new axillary shoots was increased with 1.0 
and $2.0 \mathrm{mg} \mathrm{L}^{-1} \mathrm{BA}$, and did not differ significantly from the treatment with $0.5 \mathrm{mg} \mathrm{L}^{-1} \mathrm{BA}$ for 'Burkley' (Figure 2). For 'Dover', the treatments supplemented with BA did not differ significantly (Figure 2).

Plants (both varieties) showing normal characteristics, such as long internodes, expanded leaves and root differentiation in the first 10 days of culture were observed in $100 \%$ of the cultures when BA was omitted (data not shown). The BA-free treatments exhibited significantly lower shoot proliferation than the other treatments for both strawberry varieties (Figure 2).

Hyperhydricity evolution occurred during the development of the strawberry plants in different concentrations of BA, using either Agar or Phytage ${ }^{\circledR}$ as a gelling agent (Table 1). No statistical differences were detected between varieties in response to both gelling agents. However, hyperhydricity did increase as BA concentration increased in the culture medium. At the lowest BA concentration, in Phytage ${ }^{\circledR}$-supplemented culture medium, there was a tendency to induce hyperhydricity, although this was not significant at $5 \%$ probability (Table 1). Likewise, the replacement of agar by Phytagel ${ }^{\circledR}$ induced

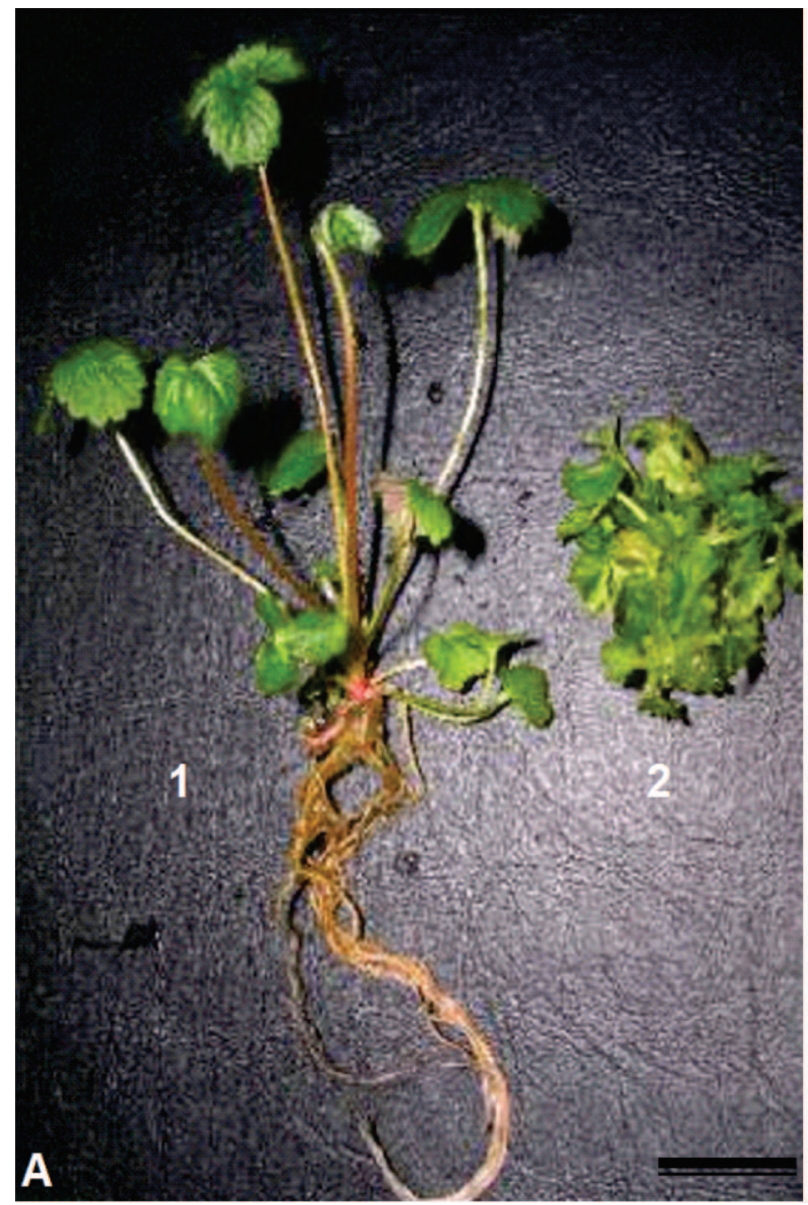

hyperhydricity in shoots of Prunus avium (Franck et al. 1997). Conversely, for apple, agar supported the shoot proliferation associated with the lowest percentages of hyperhydrated shoots (Dobránszki et al. 2011).

\section{Alterations in anatomical and ultrastructural of leaves increase with $B A$ increased concentrations}

Anatomical and ultrastructural studies of diverse species that compared hyperhydric and normal in vitrogrown plants have been reported (Picoli et al. 2008; Jausoro et al. 2010).

The normal plants showed a well-defined dorsiventral mesophyll (Figure 3A and C) with a single layer of palisade parenchyma occupying approximately half of mesophyll width. The spongy parenchyma contained two to three cell layers with few intercellular spaces. When the BA concentration increased, the delimitation of the spongy and palisade parenchyma gradually disappeared, and round and hypertrophied cells were observed with an apparent increment in leaf lamina width and reduction of its length (Figure 3B and D). The cells located below of
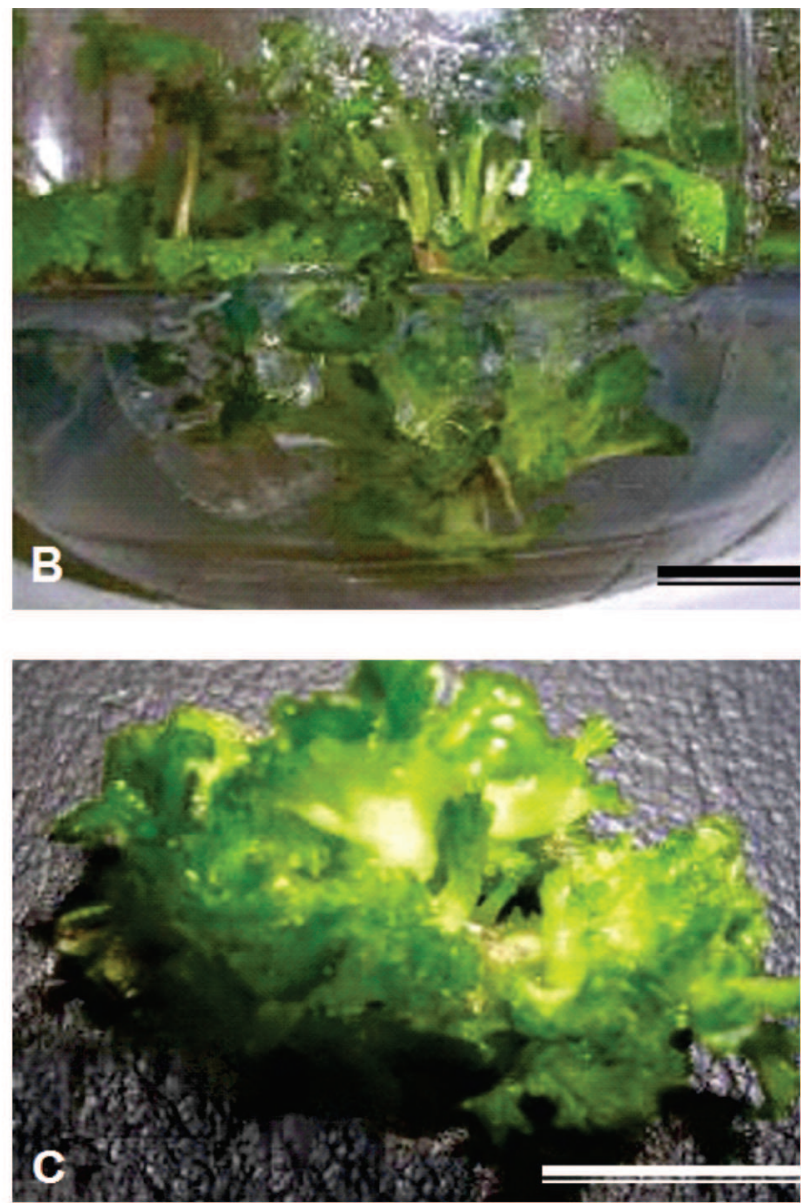

Figure 1. Strawberry shoots (Fragaria $\mathrm{x}$ ananassa). (A) Comparison of a normal plant (1) and hyperhydric plant (2) after 35 days of cultivation. (B) Detail of a hyperhydric plant of the variety 'Burkley' on MS medium. (C) Shoots of the variety 'Dover' with typical hyperhydric symptoms. 


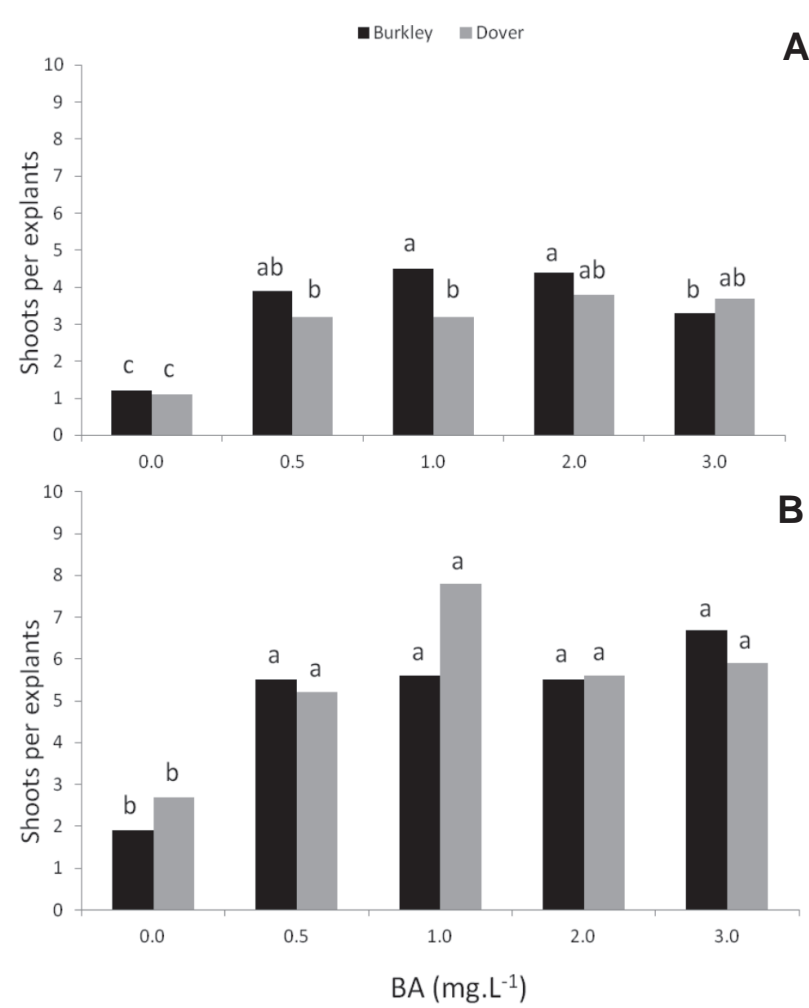

Figure 2. Mean number of shoots per explant of the varieties 'Burkley' (black bars) and 'Dover' (gray bars) under different BA concentrations in MS medium solidified with either agar (A) or Phytagel ${ }^{\circledast}(\mathbf{B})$. Bars with different letters are significantly different by the Tukey test at $5 \%$ probability.

the smaller size vascular bundles were hypertrophied, especially the epidermal cells, giving the dermal tissue of hyperhydric plants an undulated appearance.

The abaxial and adaxial surfaces of normal and hyperhydric leaves of the two strawberry varieties were analyzed using scanning electron microscopy. This analysis showed epidermal cells with plasmolysed aspect (Figure 3F and $\mathrm{HB}$ ) and lower deposition of epicuticular wax in hyperhydric plants than in the normal plants (Figure 3E and G). Structural differences were also observed between the two varieties, such as a higher deposition of epicuticular wax in the variety 'Burkley' (Figure 3F and H).

The strawberry leaf is amphistomatic, with more stomata on the abaxial surface (Figure 3). Abnormal stomata were observed in leaves of plants grown in medium with hyperhydricity inducing factors (Figure 3E and $\mathrm{G})$. These stomata were characterized by hypertrophied and deformed guard cells, unlike the typical elliptical-shaped cells found in non-hyperhydric leaves (Figure $3 \mathrm{E}$ and $\mathrm{G}$ ). Thus, the presence of hyperhydric guard cells was higher in hyperhydric leaves when compared to non-hyperhydric leaves, and these cells were deformed because the cell wall that delimits the stomatal pore was protracted and often disrupted (Figure 3F and $\mathrm{H}$ ), hence the stomata could not close properly. In addition, the irregular guard cells of the hyperhydric leaves were more round than elongated, which was probably due to a reduction in elasticity or changes in the pattern of cellulose microfibril deposition. Similar results were found in hyperhydric leaves of many plants (Picoli et al. 2008; Gupta \& Prasad 2010) with abnormalities in the guard cell morphology.

\section{Chlorophyll content in hyperhydric plants was approximately 50\% lower than the levels found in normal plants}

Throughout the development of shoots, we observed a decrease in the intensity of the green color in hyperhydric shoots when compared with the nonhyperhydric ones. Chlorophyll $a, b$ and total contents in hyperhydric plants were respectively 50, 60 and 51\% lower than the content found in normal plants (Figure 4). Similar results were reported by Sreedhar et al. (2009) in hyperhydric tissues of vanilla. The peroxidases seem to play an important role in the reduction of chlorophyll content. In spinach leaves, the chlorophyllases seem to have little involvement in the degradation of chlorophyll and peroxidases are the main enzymes involved in this process (Yamauchi \& Watada 1991).

Table 1. Hyperhydricity frequencies (\%) in strawberry plants cultured with different BA concentrations in MS medium, solidified with either Agar or Phytagel ${ }^{\circledR}$

\begin{tabular}{|c|c|c|c|c|}
\hline \multirow{3}{*}{$\mathbf{B A}\left(\mathbf{m g ~ L}^{-1}\right)$} & \multicolumn{4}{|c|}{ Hyperhydricity (\%) } \\
\hline & \multicolumn{2}{|c|}{ 'Burkley' } & \multicolumn{2}{|c|}{ 'Dover' } \\
\hline & Agar & Phytagel $^{\circledR}$ & Agar & Phytagel $^{\circledR}$ \\
\hline$\overline{0.0}$ & 0 e $\mathrm{A}$ & $0 \mathrm{c} \mathrm{A}$ & $0 \mathrm{dA}$ & $0 \mathrm{c} \mathrm{A}$ \\
\hline 0.5 & $36 \mathrm{dA}$ & $55 \mathrm{~b} \mathrm{~A}$ & $35 \mathrm{c} \mathrm{A}$ & $60 \mathrm{~b} \mathrm{~A}$ \\
\hline 1.0 & $52 \mathrm{c} \mathrm{A}$ & $64 \mathrm{~b} \mathrm{~A}$ & $56 \mathrm{~b} \mathrm{~A}$ & $60 \mathrm{~b} \mathrm{~A}$ \\
\hline 2.0 & $80 \mathrm{~b} \mathrm{~A}$ & 90 a A & 90 a A & $76 \mathrm{~b} \mathrm{~A}$ \\
\hline 3.0 & 100 a A & 80 a A & 100 a $\mathrm{A}$ & 100 a $\mathrm{A}$ \\
\hline
\end{tabular}

${ }^{1}$ Means with the same small letters in the columns or capital letters in the rows, for each variety and each BA concentration, are not significantly different by the Tukey test at $5 \%$ probability. 


\section{Antioxidant metabolism increased in hyperhydric tissues}

As noted by Saher et al. (2004), the excess water in hyperhydric tissues can lead to saturation levels causing hypoxia. Under this condition of stress, some metabolic activities in $\mathrm{H}_{2} \mathrm{O}_{2}$-generating plants can be increased, producing toxic levels of $\mathrm{H}_{2} \mathrm{O}_{2}$ and generating oxidative stress. The existence of oxidative injury in hyperhydric tissues was confirmed in this study, with the increase in the antioxidant enzyme activity and in the MDA content found in hyperhydric leaves when compared with leaves of non-hyperhydric (normal) plants.

There was an increase in the activity of the antioxidant enzymes peroxidase and catalase directly proportional to the BA concentration in the culture medium (Tables 2 and 3 ). In the variety 'Burkley', the peroxidase (POD) activity increased with the addition of BA either with agar or Phytage $^{\circledR}$. In addition, independent of the presence or absence of BA, no significant difference was detected between these gelling agents (Table 2). The results were similar for the variety 'Dover', except for treatments supplemented with agar, in which the peroxidase activity increased up to $1.0 \mathrm{mg} \mathrm{L}^{-1} \mathrm{BA}$ (Table 3).

The catalase (CAT) activity in both varieties also increased with the BA supplementation to the medium. In media with Phytagel $^{\circledR}$, the CAT activity in the variety 'Dover' (Table 3) was higher with $2.0 \mathrm{mg} \mathrm{L}^{-1} \mathrm{BA}$, while in 'Burkley' (Table 2) it was higher in both 0.5 and $1.0 \mathrm{mg} \mathrm{L}^{-1}$
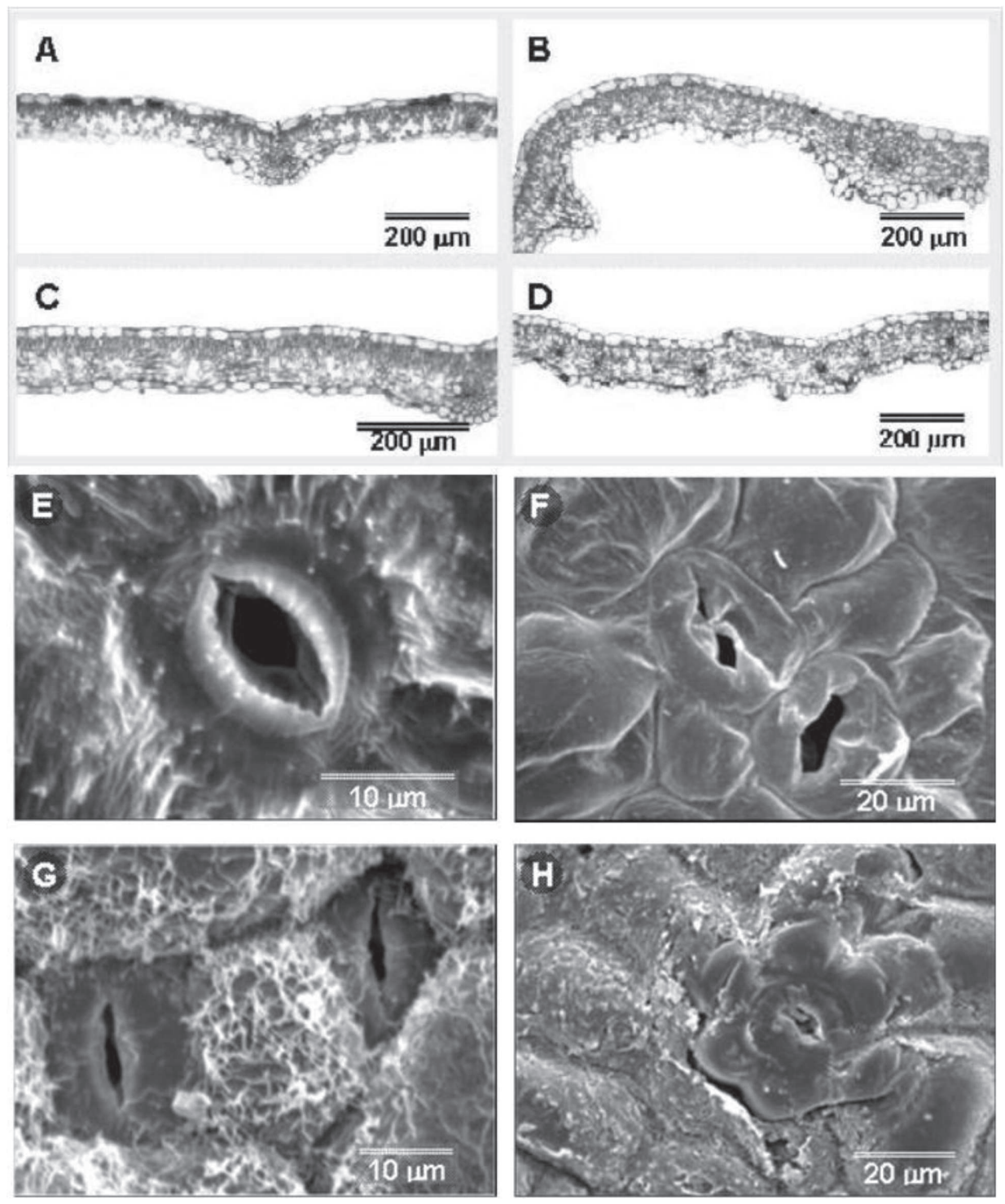

Figure 3. Toluidine Blue-stained transversal sections of strawberry (Fragaria $\mathrm{x}$ ananassa Duch.) leaves: normal (A and $\mathbf{C}$, in vitro plants propagated in medium without growth regulators, and hyperhydric (B and $\mathbf{D})$ propagated in vitro plants in culture medium with BA. Scanning electron microscopy micrographs of the abaxial surface of normal strawberry (Fragaria $\mathrm{x}$ annanassa Duch.) leaves ( $\mathbf{E}$ and $\mathbf{G}$ ) propagated in vitro in medium without plant growth regulators, and hyperhydric leaves $(\mathbf{F}$ and $\mathbf{H})$ that were propagated in vitro in medium with $3 \mathrm{mg} \mathrm{L}^{-1} \mathrm{BA}$. 
BA supplemented medium. On the other hand, when Agar was used as the gelling agent, higher catalase activities were observed in the medium with $2.0 \mathrm{mg} \mathrm{L}^{-1}$ and $3.0 \mathrm{mg} \mathrm{L}^{-}$ ${ }^{1} \mathrm{BA}$, respectively, in both varieties.

The SOD activity was significantly reduced with the addition of BA to the culture medium of the variety 'Burkley'. Conversely, for 'Dover', the SOD activity increased with the 2.0 and 0.5 to $1.0 \mathrm{mg} \mathrm{L}^{-1} \mathrm{BA}$ treatments, respectively, using agar and Phytagel ${ }^{\circledR}$ as gelling agents.
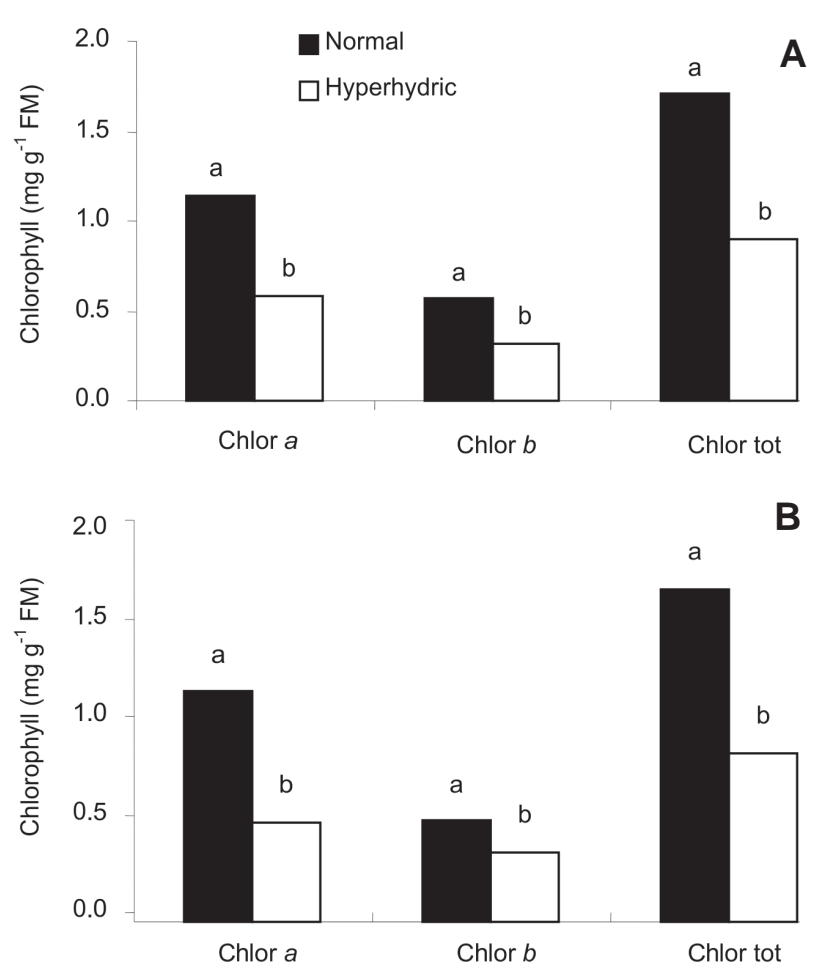

Figure 4. Chlorophyll content in normal and hyperhydric strawberry plants after 35 days in culture, varieties 'Dover' (A) 'Burkley' (B). Values represent the mean. Bars with different letters for each chlorophyll set differed significantly by the Tukey's test at $5 \%$ probability.

B

The higher peroxidase activity associated with increases in BA concentration and hyperhydricity showed a clear relationship with antioxidant enzyme activity. Among the eleven species tested, only two showed reductions in peroxidase activity, 66 and 42\%, when hyperhydric plants were compared with normal plants (Kevers et al. 1984). The others showed higher activity in hyperhydric plants in relation to the normal plants.

The varieties 'Dover' and 'Burkley' showed differences in response to the hyperhydricity induction. The latter was more sensitive, with less shoot proliferation compared with the former, showing hyperhydric characteristics in lower BA concentrations. In the variety 'Burkley', the antioxidant mechanisms were more active than in the variety 'Dover', with POD and CAT activities increased with $0.5 \mathrm{mg} . \mathrm{L}^{-1} \mathrm{BA}$ and basal levels of SOD showing a three-fold increase.

The atmospheric conditions in sealed cultures are analogous to those found in association with waterlogged soils and are associated with reduced transpiration and excessive water uptake, which can result in near hypoxic tissue oxygen concentrations and interference with respiration at the level of electron transport (RojasMartinez et al. 2010).

Lipid peroxidation was influenced by the BA and gelling agents, added to the culture medium (Table 4). The BA significantly increased the formation of the MDATBA complex and, consequently, the lipid peroxidation in both varieties. In the absence of BA, there was no significant difference between the gelling agents used in relation to lipid peroxidation.

The concentration of the MDA-TBA complex in the variety 'Burkley' was higher in the treatment with $0.5 \mathrm{mg}$ $\mathrm{L}^{-1} \mathrm{BA}$, regardless of the gelling agent (Table 4). When agar was used in the medium, the addition of 1.0 to $3.0 \mathrm{mg}$ $\mathrm{L}^{-1}$ of BA did not differ significantly in the concentration of the MDA-TBA complex, although in the absence of

Table 2. Effect of BA concentrations and gelling agents on the enzyme activity in shoot tissues of strawberry variety 'Burkley' cultured in vitro.

\begin{tabular}{|c|c|c|c|c|c|c|}
\hline \multirow{3}{*}{$\mathbf{B A}\left(\mathbf{m g ~ L}^{-1}\right)$} & \multicolumn{6}{|c|}{ Enzyme Activity $^{1}$} \\
\hline & \multicolumn{2}{|c|}{ POD $^{2}$} & \multicolumn{2}{|c|}{$\mathrm{CAT}^{3}$} & \multicolumn{2}{|c|}{ SOD $^{4}$} \\
\hline & Agar & Phytagel $^{\circledR}$ & Agar & Phytagel $^{\circledR}$ & Agar & Phytagel $^{\circledR}$ \\
\hline 0.0 & $2.15 \mathrm{~b} \mathrm{~A}$ & $2.63 \mathrm{~b} \mathrm{~A}$ & 0.09 c A & $0.07 \mathrm{c} \mathrm{A}$ & $1948.15 \mathrm{a} A$ & 1486.81 a A \\
\hline 0.5 & $20.23 \mathrm{ab} A$ & $21.39 \mathrm{ab} A$ & $0.46 \mathrm{c} \mathrm{B}$ & $4.07 \mathrm{a} \mathrm{A}$ & 261.66 c B & 320.43 b A \\
\hline 1.0 & $24.36 \mathrm{ab} \mathrm{A}$ & $26.72 \mathrm{ab} A$ & $2.21 \mathrm{~b} \mathrm{~A}$ & 3.39 a B & $537.08 \mathrm{~b} \mathrm{~A}$ & 287.08 b B \\
\hline 2.0 & $34.72 \mathrm{a} \quad \mathrm{A}$ & 34.44 a A & $3.31 \mathrm{a} \mathrm{A}$ & $2.37 \mathrm{~b} \mathrm{~B}$ & $151.90 \mathrm{c} \mathrm{A}$ & 93.80 с B \\
\hline 3.0 & 43.80 a $\mathrm{A}$ & 45.63 a A & $2.46 \mathrm{ab} \mathrm{A}$ & $2.46 \mathrm{~b} \mathrm{~A}$ & $157.86 \mathrm{c} \mathrm{B}$ & $372.93 \mathrm{~b} \mathrm{~A}$ \\
\hline
\end{tabular}

${ }^{1}$ Means with the same small letters in the columns or capital letters in the rows are not significantly different by the Tukey test at $5 \%$ probability.

${ }^{2}$ POD - Peroxidase (mmoles $\mathrm{min}^{-1} \mathrm{mg}^{-1}$ Fresh Mass - FM).

${ }^{3}$ CAT - Catalase (mmoles $\left.\mathrm{min}^{-1} \mathrm{mg}^{-1} \mathrm{FM}\right)$.

${ }^{4} \mathrm{SOD}$ - Superoxide dismutase (SOD units $\mathrm{min}^{-1} \mathrm{~g}^{-1} \mathrm{FM}$ ). 
Table 3. Effect of BA concentrations and gelling agents on the enzyme activity in shoot tissues of strawberry variety 'Dover' cultured in vitro

\begin{tabular}{|c|c|c|c|c|c|c|c|c|}
\hline \multirow{3}{*}{$\mathbf{B A}\left(\mathrm{mg} \mathrm{L}^{-1}\right)$} & \multicolumn{8}{|c|}{ Enzyme Activity $^{1}$} \\
\hline & \multicolumn{4}{|c|}{ POD $^{2}$} & \multicolumn{2}{|c|}{ CAT $^{3}$} & \multicolumn{2}{|c|}{ SOD $^{4}$} \\
\hline & Agar & & Phytagel $^{\circledR}$ & & Agar & Phytage $^{\circledR}$ & Agar & Phytage $^{\circledR}$ \\
\hline 0.0 & 3.50 & $\mathrm{~d} A$ & 3.64 & e A & $0.06 \mathrm{c} \mathrm{A}$ & $0.11 \mathrm{c} \mathrm{A}$ & $585.99 \mathrm{~b} \mathrm{~A}$ & $587.51 \quad \mathrm{~b} \mathrm{~A}$ \\
\hline 0.5 & 32.14 & $\mathrm{c} \mathrm{A}$ & 42.90 & $\mathrm{~d} A$ & 0.19 c A & $0.51 \mathrm{c} \mathrm{B}$ & 599.84 b B & 816.49 a A \\
\hline 1.0 & 106.97 & a A & 56.28 & $\mathrm{cB}$ & $0.30 \mathrm{bc} \mathrm{A}$ & $0.31 \mathrm{c} \mathrm{A}$ & 383.28 с B & 879.07 a A \\
\hline 2.0 & 93.71 & $\mathrm{~b} A$ & 78.81 & $\mathrm{~b} A$ & $0.91 \mathrm{~b} \quad \mathrm{~A}$ & $1.86 \mathrm{~b} \mathrm{~A}$ & 1204.83 a A & 364.46 с B \\
\hline 3.0 & 101.64 & $\mathrm{ab} A$ & 108.49 & a B & $3.78 \mathrm{a} \mathrm{A}$ & 3.69 a A & $643.29 \mathrm{~b} \mathrm{~A}$ & 489.84 bc B \\
\hline
\end{tabular}

${ }^{1}$ Means with the same small letters in the columns or capital letters in the rows are not significantly different by the Tukey test at $5 \%$ probability.

${ }^{2}$ POD - Peroxidase (mmoles $\mathrm{min}^{-1} \mathrm{mg}^{-1}$ Fresh Mass - FM).

${ }^{3} \mathrm{CAT}$ - Catalase (mmoles $\mathrm{min}^{-1} \mathrm{mg}^{-1} \mathrm{FM}$ ).

${ }^{4} \mathrm{SOD}$ - Superoxide dismutase (SOD units $\min ^{-1} \mathrm{~g}^{-1} \mathrm{FM}$ ).

Table 4. Effect of BA concentrations and gelling agents on the lipid peroxidation in shoot tissues of strawberry varieties 'Burkley' and 'Dover' cultured in vitro

\begin{tabular}{|c|c|c|c|c|}
\hline \multirow{3}{*}{ BA $\left(\mathbf{m g ~ L}^{-1}\right)$} & \multicolumn{4}{|c|}{ Lipid peroxidation (nmoles de MDA-TBA g ${ }^{-1}$ FM) } \\
\hline & \multicolumn{2}{|c|}{ 'Burkley' } & \multicolumn{2}{|c|}{ 'Dover' } \\
\hline & Agar & Phytagel $^{\circledR}$ & Agar & Phytagel $^{\circledR}$ \\
\hline 0.0 & $3.94 \mathrm{c} \mathrm{A}$ & $4.43 \mathrm{~b} \mathrm{~A}$ & $6.41 \mathrm{c} \mathrm{A}$ & $7.85 \mathrm{c} \mathrm{A}$ \\
\hline 0.5 & 44.81 a A & 27.18 a A & $12.82 \mathrm{~b} \mathrm{~B}$ & $37.66 \mathrm{a} \mathrm{A}$ \\
\hline 1.0 & $18.21 \mathrm{~b} \mathrm{~A}$ & 26.70 a A & $15.16 \mathrm{~b} \mathrm{~A}$ & $12.16 \mathrm{c} \mathrm{A}$ \\
\hline 2.0 & $17.40 \mathrm{~b} \mathrm{~A}$ & 18.69 a A & 36.70 a $\mathrm{A}$ & $15.87 \mathrm{bc} \mathrm{B}$ \\
\hline 3.0 & $17.63 \mathrm{~b} \mathrm{~B}$ & 23.33 a A & $11.11 \mathrm{~b} \mathrm{~A}$ & $24.04 \mathrm{~b} \quad \mathrm{~A}$ \\
\hline
\end{tabular}

${ }^{1}$ Means followed by same small letters in the columns or capital letters in the rows for each variety and for each BA concentration, are not significantly different by the Tukey test at $5 \%$ probability.

$\mathrm{BA}$, reduction in the concentration of this complex could be seen. When using Phytage ${ }^{\circledR}$, the absence of BA reduced the formation of the MDA-TBA complex. This result was significant in relation to treatments containing BA, but did not differ among the BA concentrations. Although the treatment with $0.5 \mathrm{mg} \mathrm{L}^{-1} \mathrm{BA}$ showed higher levels of the MDA-TBA complex, it did not differ significantly from other treatments with BA.

In the variety 'Dover' (Table 4), the concentration of the MDA-TBA complex was higher in the presence of 0.5 mg L ${ }^{-1} \mathrm{BA}$, when Phytage ${ }^{\circledR}$ was the gelling agent, and differed significantly from the other treatments. However, the use of agar resulted in an increase, but this was only significant in the presence of $2.0 \mathrm{mg} \mathrm{L}^{-1} \mathrm{BA}$, when compared with the other treatments with and without BA.

\section{CONCLUSIONS}

In conclusion, the present study has provided insights into the morphological and biochemical changes that occur during the progression of hyperhydricity in strawberry propagated in vitro; mainly in increased cytokinin concentration and when agar was replaced by Phytage ${ }^{\circledR}$. The rapid loss of chlorophyll and the concurrent increase in antioxidant enzyme activity are useful biochemical indicators of hyperhydricity in strawberry. The culture medium containing $0.5 \mathrm{mg} \mathrm{L}^{-1}$ BA and solidified with Agar promoted lower hyperhydricity percentages in relation to the higher rates of shoot proliferation and should be applied for efficient strawberry in vitro propagation.

\section{ACKNOLEDGEMENTS}

The authors would like to acknowledge the scholarship awarded to LMPM by CAPES (Brasília, DF, Brazil), as well as the research fellowship awarded to WCO by $\mathrm{CNPq}$ (Brasília, DF, Brazil). The authors also wish to thank the Núcleo de Microscopia e Microanálises from Universidade Federal de Viçosa.

\section{REFERENCES}

Balen B, Peharec P, Tkalec M \& Krsnik-Rasol M (2011) Oxidative stress in horseradish (Armoracia lapathifolia Gilib.) tissues grown in vitro. Food Technology and Biotechnology 49:32-39.

Buege JA \& Aust SD (1978) Microsomal lipid peroxidation. Methods in Enzymology, 52:302-310.

Calvete EO, Grando MF, Gomide DG, Maran RE, Suzin M, Hienow AA \& Cecchetti D (2009) Agronomic and in vitro performance of micropropagated strawberry cultivars in different numbers of subculture. Revista Brasileira de Fruticultura, 31:943-949. 
Casanova E, Moysset L \& Trillas MI (2008) Effects of agar concentration and vessel closure on the organogenesis and hyperhydricity of adventitious carnation shoots. Biologia Plantarum, 52:1-8.

Chance B \& Maehley AC (1955) Assay of catalases and peroxidases. Methods in Enzymology, 2:764-775.

Dhindsa RS, Plumb-Dhindsa P \& Thorpe TA (1981) Leaf senescence: correlated with increased levels of membrane permeability and lipid peroxidation, and decreased levels of superoxide dismutase and catalase. Journal of Experimental Botany, 32:93-101.

Dobránszki J, Magyar-Tábori K \& Tombácz E (2011) Comparison of the rheological and diffusion properties of some gelling agents and blends and their effects on shoot multiplication. Plant Biotechnology Reports, 5:345-352.

Franck T, Crévecoeur M, Wuest J, Greppin H \& Gaspar T (1997) Cytological comparison of leaves and stems of Prunus avium L. shoots cultured on a solid medium with agar or gelrite. Biotechnic Histochemistry, 73:32-43.

Giannopolitis CN \& Ries SK (1977) Superoxide dismutases I Occurence in higher plants. Plant Physiology, 59:309-314.

Gupta SD \& Prasad VSS (2010) Shoot multiplication kinetics and hyperhydric status of regenerated shoots of gladiolus in agarsolidified and matrix-supported liquid cultures. Plant Biotechnology Reports, 4:85-94.

Havir EA \& McHale NA (1987) Biochemical and developmental characterization of multiple forms of catalase in tobacco leaves. Plant Physiology, 84:450-455.

Hendry GAF \& Price AH (1993) Methods of comparative study anatomy: stress indicators - chlorophylls and carotenoids. In: Hendry GAF, Grime KP (eds) Methods in comparative plant ecology. London, Champman \& Hall. p. 148-152.

Ivanova M \& van Staden J (2011) Influence of gelling agent and cytokinins on the control of hyperhydricity in Aloe polyphylla. Plant Cell, Tissue and Organ Culture, 104:13-21.

Jain A, Kantia A \& Kothari SL (2001) De novo differentiation of shoot buds from leaf-callus of Dianthus caryophyllus L. and control of hyperhydricity. Scientia Horticulturae, 87:319-326.
Jausoro V, Llorente BE \& Apóstolo NM (2010) Structural differences between hyperhydric and normal in vitro shoots of Handroanthus impetiginosus (Mart. ex DC) Mattos (Bignoniaceae). Plant Cell, Tissue and Organ Culture, 101:183-191.

Karnovsky MJ (1965) A formaldehyde-glutaraldehyde fixative of high osmolality for use in electron microscopy. Journal of Cell Biology, 27:137-138.

Kevers C, Coumans M, Coumans-Gilles MF \& Gaspar T (1984) Physiological and biochemical events leading to vitrification of plants cultured in vitro. Physiologia Plantarum, 61:69-74.

Kumar A, Aggarwal D, Gupta P \& Reddy MS (2010) Factors affecting in vitro propagation and field establishment of Clorophytum borivilianum. Biologia Plantarum, 54:601-606.

Picoli EAT, Paiva EAS, Xavier A, Aguiar RM, Carolino SMB, Fári MG \& Otoni WC (2008) Ultrastructural and biochemical aspects of normal and hyperhydric eucalypt. International Journal Horticultural Science, 14:61-69.

Rojas-Martinez L, Visser RGF \& Klerk GJ (2010) The hyperhydricity syndrome: waterlogging of plant tissues as a major cause. Propagation Ornamental Plants, 10:169-175.

Saher S, Piqueras A, Hellín E \& Olmos E (2004) Hyperhydricity in micropropagated carnation shoots: the role of oxidative stress. Physiologia Plantarum, 120:152-161.

Sreedhar RV, Venkatachalam L \& Neelwarne B (2009) Hyperhydricity-related morphologic and biochemical changes in Vanilla (Vanilla planifolia). Journal of Plant Growth Regulation, 28:46-57.

Wu Z, Chen LJ \& Long YJ (2009) Analysis of ultrastructure and reactive oxygen species of hyperhydric garlic (Allium sativum L.) shoots. In Vitro Cellular and Developmental Biology-Plant, 45:483-490.

Yamauchi N \& Watada AE (1991) Regulated chlorophyll degradation in spinach leaves during storage. Journal of American Society of Horticultural Science, 116:58-62. 